\title{
PENINGKATAN PEMAHAMAN PASIEN DIABETES MELLITUS TIPE 2 TERHADAP OBAT ANTI DIABETES ORAL DI KLINIK PENYAKIT DALAM RUMAH SAKIT ADI HUSADA KAPASARI SURABAYA
}

\author{
ROBERTO GOENARSO, PRISKA ANASTASYA \\ AKADEMI KEPERAWATAN ADI HUSADA SURABAYA \\ totogoenarso@gmail.com
}

\begin{abstract}
ABSTRAK
Diabetes Melitus merupakan kelainan kelompok penyakit metabolisme yang dengan manifestasi klinis hiperglikemia akibat dari defek sekresi insulin, atau karena intoleransi insulin maupun keduanya. Penelitian ini bertujuan untuk memberikan edukasi dan mengevaluasi hasil edukasi farmasis terhadap tingkat pemahaman pasien diabetes mellitus yang menggunakan obat anti diabetes oral di RS Adi Husada Kapasari Surabaya pada bulan April 2015. Penelitian dilakukan menggunakan metode pre-experimental design. Sampel penelitian yaitu 30 pasien yang menerima obat antidiabetes oral di Klinik Penyakit Dalam RS Adi Husada Kapasari Surabaya. Data diperoleh dari edukasi disertai kuisioner sebelum dan sesudah edukasi. Data dianalisis secara deskriptif dan kuantitatif menggunakan uji Paired T-Test Sample. Hasil penelitian menunjukkan bahwa ada peningkatan pemahaman setelah pasien diberikan edukasi $(\mathrm{p}=0.00, \alpha<0.05)$. Peran farmasis dalam memberikan edukasi adalah untuk mengukur seberapa besar pemahaman, pengetahuan dan keterampilan pasien untuk menjalankan regimen terapi dan rencana monitoring.
\end{abstract}

Kata Kunci: edukasi farmasis, obat antidiabetes oral, pemahaman.

\section{ABSTRACT}

Diabetes Mellitus is a dysfunction metabolism disease that characterized by hyperglycemia caused by insulin secretion defect or insulin's activity or both. Aims of this study was to provide education and evaluating the results of education of pharmacists on the level of understanding of patients with diabetes mellitus who use oral anti-diabetic medication in hospital Adi Husada Kapasari Surabaya in April 2015. The study was conducted using pre-experimental design. The research sample were 30 patients receiving oral antidiabetic drugs in Clinical Medicine Hospital Surabaya Adi Husada Kapasari. Data obtained from questionnaires accompanied education before and after education. Data were analyzed descriptively and quantitatively using Paired T-Test Sample. The results show that there is an increased understanding after the patient is given education $(p=0.00, \alpha<0.05)$. The role of pharmacists in providing education is to measure how much understanding, knowledge and skills to carry out the treatment regimen of patients and the monitoring plan.

Keywords: pharmacy's education, oral medicine of anti-diabetes, understanding 


\section{PENDAHULUAN}

Diabetes Mellitus adalah kelompok penyakit metabolisme yang dikarakterisasi oleh hiperglikemia akibat dari defek sekresi insulin, atau karena kerja dari insulin maupun keduanya (American Diabetes Association, 2013). Diabetes Mellitus juga disebutkan sebagai sindrom klinis yang dikarakterisasi dengan hiperglikemia baik karena defisiensi insulin absolut atau relatif, atau kombinasi dari resistensi insulin dan ketidakcukupan sekresi insulin untuk kompensasi. ${ }^{1}$

Menurut International Diabetes Federation (IDF) tahun 2009, 285 juta penduduk dunia menderita Diabetes Mellitus dan meningkat menjadi 438 juta jiwa tahun 2025. Sedangkan secara global 366 juta orang menderita Diabetes Mellitus pada tahun 2011 akan meningkat menjadi 522 juta pada tahun 2030. Kematian karena Diabetes Mellitus, $80 \%$ terjadi di negara miskin dan negara berkembang. Dan setengahnya, terjadi pada mereka yang berusia di bawah 70 tahun, yang mana 55\% kematian terbanyak dialami oleh wanita.

Indonesia menempati urutan ke-4 dengan jumlah penderita Diabetes Mellitus terbanyak dengan prevalensi $8,6 \%$ dari total penduduk, diikuti oleh India, China dan Amerika Serikat. Temuan tersebut semakin membuktikan bahwa Diabetes Mellitus merupakan masalah kesehatan masyarakat yang sangat serius di indonesia. Mengingat bahwa Diabetes Mellitus akan memberikan dampak terhadap kualitas dan sumber daya manusia serta peningkatan biaya kesehatan yang cukup besar, semua pihak baik masyarakat maupun pemerintah wajib ikut serta dalam usaha penanggulangan Diabetes Mellitus, khususnya upaya pencegahan.

Mengingat pengetahuan tentang Diabetes Mellitus sangat penting untuk meningkatkan kualitas hidup masyarakat, maka peneliti berkehendak untuk mengukur seberapa besar tingkat pemahaman pasien sebelum dan sesudah diberikan edukasi atau konseling tentang obat anti diabetes oral (OAD) serta mengecek gula darah pasien. Pasien yang paham akan pentingnya menjaga lifestyle dan pola makan akan mengurangi resiko terkena penyakit Diabetes Mellitus, serta paham akan penggunaan obat yang di terima dapat mencegah adanya komplikasi lanjut yang dapat menyebabkan kematian. Tujuan dilakukan konseling, yaitu agar dapat mengubah pola pikir, pengetahuan dan pemahaman pasien, dalam hal ini seorang farmasis harus berinteraksi dengan pasien dan tenaga kesehatan lainnya dengan komunikasi yang efektif untuk memberikan pengertian ataupun pengetahuan tentang obat dan penyakit. Pengetahuan yang dimilikinya diharapkan dapat menjadi titik tolak perubahan sikap dan gaya hidup pasien yang pada akhirnya akan merubah perilakunya serta dapat meningkatkan pemahman pasien terhadap pengobatan yang dijalaninya. Komunikasi antara farmasis dengan pasien merupakan salah satu bentuk implementasi dari Pharmaceutical care. ${ }^{5}$

Penelitan ini dilakukan di KlinikPenyakit Dalam di rumah sakit Adi Husada Kapasari di Surabaya karena rumah sakit Adi Husada Kapasari di Surabaya memiliki pencatatan pengobatan pasien yang baik dalam membantu peneliti dalam mencari pasien Diabetes Mellitus yang memenuhi kriteria penelitian.

Sasaran dari penelitian ini adalah pasien KlinikPenyakit Dalam di Rumah Sakit Adi Husada Kapasari di Surabaya yang memenuhi kriteria inklusi penelitian. Pasien Klinik Penyakit Dalam yang digunakan untuk sampling adalah pasien baru dan pasien lama Diabetes Mellitus tipe 2 yang berobat dan memiliki catatan medis di Rumah Sakit Adi Husada Kapasari Surabaya yang menebus resep pada bulan April 2015 dan memenuhi kriteria inklusi. Penelitian ini bertujuan untuk memberikan edukasi dan mengevaluasi hasil edukasi farmasis terhadap tingkat pemahaman pasien diabetes mellitus yang menggunakan obat anti diabetes oral di RS Adi Husada Kapasari Surabaya pada bulan April 2015.

\section{METODE}

Populasi penelitian adalah pasien baru dan pasien lama Diabetes Mellitus tipe 2 di Klinik Penyakit Dalam Rumah Sakit Adi Husada Kapasari Surabaya dan memenuhi kriteria inklusi penelitian.

Metode yang akan digunakan dalam penelitian ini, yaitu survey research method. Sampel dipilih secara consecutive sampling.

Penelitian ini menggunakan pretest sebelum perlakuan dan posttest setelah perlakuan, dengan rancangan yang digunakan adalah One Group Pretest - Posttest Design. Pertanyaan kuisioner telah diuji validitas dan 
reliabilitasnya dengan menggunakan bantuan software komputer SPSS.

Dalam penelitian ini digunakan satu kelompok subjek yang sebelumnya dilakukan pengukuran, lalu dikenakan perlakuan, kemudian dilakukan pengukuran untuk kedua kalinya. Menggunakan metode terpilih Paired T-Test untuk membandingkan dua perilaku berbeda pada satu subjek yang sama.

HASIL

Data Umum

Tabel 1 Karakteristik Responden

\begin{tabular}{|c|c|c|c|}
\hline No & Responden & $\mathrm{n}$ & $\%$ \\
\hline \multirow[t]{3}{*}{1} & Jenis kelamin & & \\
\hline & Laki-laki & 9 & 30 \\
\hline & Perempuan & 21 & 70 \\
\hline \multirow[t]{5}{*}{2} & Pendidikan terakhir & & \\
\hline & SD & 7 & 23.33 \\
\hline & SMP & 10 & 33.33 \\
\hline & SMA & 8 & 26.67 \\
\hline & PT & 5 & 16.67 \\
\hline \multirow[t]{7}{*}{3} & Penghasilan & & \\
\hline & $<\operatorname{Rp} 1.000 .000,00$ & 7 & 23.3 \\
\hline & $\mathrm{Rp} 1.000 .000,00<$ & 10 & 33.3 \\
\hline & $\mathrm{Rp} 2.000 .000,00$ & & \\
\hline & $\mathrm{Rp} \quad 2.000 .000,00<$ & 9 & 30 \\
\hline & Rp 3.000.000,00 & & \\
\hline & $>\operatorname{Rp} 3.000 .000,00$ & 4 & 13.3 \\
\hline \multirow[t]{3}{*}{4} & Umur & & \\
\hline & $41-60$ tahun & 18 & 60 \\
\hline & $>60$ tahun & 12 & 40 \\
\hline \multirow[t]{4}{*}{5} & Pekerjaan & & \\
\hline & Ibu rumah tangga & 11 & 36.67 \\
\hline & Wiraswasta & 10 & 33.33 \\
\hline & PNS & 1 & 3.33 \\
\hline
\end{tabular}

Tabel 1 menunjukkkan responden mayoritas adalah perempuan yaitu 21 pasien (70\%), berpendidikan terakhir SMP yaitu 10 pasien (33.33\%), berpenghasilan Rp. $1.000 .000,00<$ Rp. $2.000 .000,00$ yaitu 10 pasien $(33.33 \%)$, mayoritas berusia 41-60 tahun yaitu 18 pasien $(60 \%)$ dan bekerja sebagai ibu rumah tangga yaitu 11 pasien $(36.67 \%)$.

\section{Data Khusus}

Tabel 2 Tabulasi pemahaman responden terhadap OAD

\begin{tabular}{llcc}
\hline No & Tingkat pemahaman & n & \% \\
\hline 1 & Turun & 0 & 0 \\
\hline 2 & Tetap & 6 & 20 \\
\hline 3 & Naik & 24 & 80 \\
\hline
\end{tabular}

Uji paired t test $\mathrm{p}=0.00(\alpha<0.05)$
Tabel 2 menunjukkan tingkat pemahaman responden mayoritas meningkat yaitu 24 pasien $(80 \%)$.

\section{PEMBAHASAN}

Menurut Holt dan Fatehi (2010), penyebab penyakit Diabetes Mellitus beragam dengan karakteristik adanya hiperglikemia kronis disertai dengan gangguan metabolisme karbohidrat, protein dan lemak sebagai akibat dari gangguan sekresi insulin dan penurunan aktivitas insulin, yang dapat disebabkan oleh faktor keturunan atau disebabkan oleh gaya hidup. Dalam rangka pengendalian penyakit Diabetes Mellitus, edukasi merupakan proses pendidikan kesehatan bagi individu maupun keluarga dalam memfasilitasi pasien untuk meningkatkan pengetahuan dan keterampilan alam mengelola penyakit DM. ${ }^{16}$

Dalam meningkatkan pemahaman pasien, face-to-face interventions merupakan cara paling efektif dibandingkan dengan phone contact intervention. ${ }^{17}$ Melalui tatap muka dan bertemu langsung, pasien lebih interaktif untuk bertanya dan sharing kepada peneliti dalam menceritakan penyakitnya. Pasien dengan usia tua justru lebih menerima kunjungan edukasi dari peneliti dibandingkan dengan pasien usia produktif. Ini disebabkan karena pada usia produktif, lebih banyak menggunakan waktu untuk bekerja dan banyak melakukan aktivitas pribadi. Pasien dengan usia tua juga membutuhkan perhatian dan motivasi, sehingga dengan adanya home visite education membuat pasien menjadi lebih diperhatikan dan membantu pasien dalam menerapkan pola hidup yang baik yang menimbulkan pemahaman dan kepatuhan minum obat lebih baik dari sebelumnya. Faktor dukungan keluarga juga mempengaruhi selfcare pada pasien. Motivasi dan dukungan dari keluarga ini dinilai penting untuk meningkatkan outcome dalam menjalankan terapi diabetes. Izzah et al mengemukakan bahwa motivasi pasien Diabetes Mellitus merupakan peran farmasis dalam manajemen program Diabetes Mellitus dan ada korelasi antara pemahaman pasien dengan kepatuhan dan menurunnya kadar gula darah yang tinggi.

Peran farmasis dalam memberikan edukasi adalah untuk mengukur seberapa besar pemahaman, pengetahuan dan keterampilan pasien untuk menjalankan 
regimen terapi dan rencana monitoring. Peran pasien dalam edukasi adalah untuk patuh terhadap regimen terapi, ikut memonitor efek samping obat, aktif dalam mencari informasi dan membagi pengalaman dalam menjalankan terapi kepada farmasis. ${ }^{14}$

Usia mempengaruhi tingkat pemahaman dan kemudahan subyek dalam menerima informasi yang diberikan. Subyek yang berusia lanjut mendapat skor pengetahuan lebih rendah serta kurang dapat menerima edukasi mengenai Diabetes Mellitus dan saran untuk melakukan perilaku sehat. ${ }^{4}$ Berdasarkan penelitian Nasrul (2011) mengemukakan bahwa makin tua umur seseorang maka proses perkembangan mentalnya bertambah baik, akan tetapi pada umur tertentu bertambahnya proses perkembangan mental ini tidak secepat seperti ketika berumur belasan tahun atau umur produktif. Seorang pasien penderita Diabetes Mellitus usia lanjut cenderung tidak mudah untuk menerima informasi baru atau perkembangan yang menunjang derajat kesehatannya. Hal tersebut disebabkan karena proses berpikir yang dimiliki oleh responden mengalami penurunan dalam hal mengingat dan menerima sesuatu hal yang baru. Seorang pasien dengan Diabetes Mellitus yang telah berusia lanjut akan kesulitan dalam menerima informasi seputar kesehatan yang pada akhirnya akan menurunkan pengetahuan responden itu sendiri. ${ }^{8}$

Bila diperhatikan lebih lanjut, ternyata tingkat pendidikan yang semakin tinggi mempengaruhi tingkat pengetahuan pasien tentang penyakit yang dialaminya. Pasien yang memiliki pendidikan terbatas mendapat skor pemahaman lebih rendah serta kurang dapat menerima edukasi mengenai Diabetes Mellitus dan saran untuk melakukan perilaku sehat. ${ }^{2}$ Notoatmodjo (2005) menyebutkan bahwa pendidikan adalah suatu kegiatan atau proses pembelajaran untuk mengembangkan atau meningkatkan kemampuan tertentu sehingga sasaran pendidikan itu dapat berdiri sendiri. Semakin rendah tingkat pendidikan yang dimiliki maka akan semakin rendah pula kemampuan yang akan dimiliki seseorang dalam menyikapi suatu permasalahan. Seorang pasien Diabetes mellitus yang memiliki latar belakang pendidikan kurang atau tingkatan dasar, cenderung tidak dapat menerima perkembangan baru terutama yang menunjang derajat kesehatannya. Hal ini dikarenakan pendidikan dasar merupakan tingkatan pendidikan untuk sekedar mengenalkan ilmu baru tanpa adanya proses nalar dan pertimbangan akan suatu ilmu. Responden yang memiliki latar belakang pendidikan yang kurang akan mengalami kesulitan untuk menerima informasi baru karena proses berpikir yang telah tertanam dalam dirinya hanyalah bersifat sementara karena tidak adanya proses nalar yang cukup dari penderita diabetes mellitus itu sendiri yang dikarenakan latar belakang pendidikan yang dimiliki. Namun pada data penelitian di atas di peroleh hasil nilai skor tertinggi pada pendidikan SD dan SMP, sehingga untuk tingkat pendidikan tersebut tidak mempengaruhi tingkat pemahaman pasien tentang penyakit Diabetes Mellitus dan obat antidiabetes oral.

Hal tersebut dapat dilihat bahwa aktivitas pasien tidak telalu berat. Meskipun demikian pasien yang memiliki pekerjaan tidak mempengaruhi untuk lebih mudah dalam menerima informasi dan diajak bekerja sama dalam proses edukasi. Responden yang bekerja akan cenderung menghabiskan waktu yang dimiliki untuk aktivitas pekerjaannya sehingga mengurangi waktu untuk dapat mencari informasi seputar kesehatan yang berguna bagi derajat kesehatannya. Namun jika dalam aktivitas pekerjaan yang dilakukan, seorang penderita Diabetes Mellitus masih dapat meluangkan waktu yang ada untuk mencari informasi baru mengenai diabetes mellitus maupun pengobatannya akan menjadikan penderita Diabetes Mellitus mengerti dan paham mengenai tata laksana Diabetes Mellitus sebagai salah satu cara untuk menjaga kondisi gula darah dalam keadaan baik dan normal.

Dengan pola hidup sehat dan tetap mengontrol gula darah, maka biaya untuk pengobatan dapat diatur dan dengan tidak terjadinya komplikasi yang lebih lanjut maka biaya pengobatan tidak semakin membesar.

\section{SIMPULAN}

Ada pengaruh pemberian edukasi yaitu terjadi peningkatan pemahaman pasien mengenai diabetes dan obat antidiabetes oral. Pasien dalam menerapkan pola hidup yang baik yang menimbulkan pemahaman dan 
kepatuhan minum obat lebih baik dari sebelumnya.

\section{KEPUSTAKAAN}

1. Abrams, A. C.. 2013. Clinical Drug Therapy. 10th ed.. Philadelphia: Lippincott Williams \& Wilkins.

2. American Diabetes Association. 2012. Diabetes: Updates on ADA Guidelines. America.

3. American Diabetes Association. 2013. Diabetes Professional Resources Online., [Online], http://professional.diabetes.org/Glucose Calculator.aspx. [2013, Oktober].

4. American Diabetes Association. 2013. Standards of Medical Care in Diabetes, Vol.36. America.

5. Arikunto, S.. 2006. Prosedur Penelitian: Suatu Pendekatan Praktek. $6^{\text {th }}$ ed. Jakarta: PT. Rineka Cipta.

6. Direktorat Bina Farmasi Komunitas dan Klinik Direktorat Jenderal Bina Kefarmasian dan Alat Kesehatan. 2005. Pharmaceutical Care Untuk Penyakit Diabetes Mellitus. Jakarta: Departemen Kesehatan RI.

7. International Diabetes Federation. 2005. Global Guideline for Type 2 Diabetes. Belgium: Brussels.

8. International Diabetes Federation. 2012. Global Guideline for Type 2 Diabetes. Belgium: Brussels.

9. Isworo, A., dan Saryono. 2010. The Soedirman Journal of Nursing: Hubungan Depresi dan Dukungan Keluarga

10. Nasrul, H. P. 2011. Hubungan Pengetahuan Tentang Diet Diabetes Mellitus Dengan Kepatuhan Pelaksanaan Diet Pada Penderita Diabetes Mellitus. Jurnal Keperawatan. Vol. 1, No. 1, Madura.

11. PERKENI. $2006 . \quad$ Konsensus Pengelolaan dan Pencegahan Diabetes Melitus Tipe 2 di Indonesia. Jakarta.

12. Priyatno, D. 2010. Paham Analisa Statistik Data dengan SPSS. Yogyakarta: MediaKom.

13. Schernthaner, G., Craig, J. C., and GeritHolger, S. 2013. Do We Still Need Pioglitazone for the Treatment of Type 2 Diabetes? A Risk-Benefit Critique in 2013, Diabetes Care Journal. Vol. 36, Rudolfstiftung Hospital, Vienna,
Austria.

14. Sugiyono. 2008. Metode Penelitian Kuantitatif, Kualitatif dan R\&D. Edisi 4, CV Alvabeta, Bandung.

15. Sutandi, A. 2012. DSME sebagai Metode Alternatif Dalam Perawatan Mandiri Pasien Diabetes Mellitus di Dalam Keluarga. Volume 29, Jakarta. 